\title{
BASOPHILS OF HUMAN PITUITARY PARS INTERMEDIA
}

\author{
Savithri Krishnan *1, Aleyamma Fenn ${ }^{2}$. \\ ${ }^{*}$ Professor in Anatomy, Govt Medical College, Kollam, Kerala, India. \\ ${ }^{2}$ Professor in Anatomy, Govt Medical College, Palaghat, Kerala, India. \\ ABSTRACT
}

Back ground and Purpose: The human pituitary gland, also called the endocrine band master, has three parts- the pars anterior, intermedia and nervosa. The pars intermedia is the least explored part of the endocrine bandmaster. The present study aims to demonstrate the basophilic cells of the human pituitary pars intermedia at various ages of life.

Materials and Methods: From postmortem and fetal autopsies 83 specimens of the pituitary gland were collected. These included specimens from fetuses above 18 weeks of gestation to that of an 80 year old man. After routine histological processing, the slides were subjected to histological and histochemical staining methods.

Results: Basophils formed the majority of cells in the pars intermedia of the pituitary. These basophils contained mucoproteins and ACTH/MSH granules as revealed by histochemical staining methods. The basophils invaded the pars nervosa and this basophilic invasion increased as age advanced. These invading cells were similar to the basophils in pars intermedia. They also contained mucoproteins and ACTH/MSH granules in the cytoplasm.

Conclusion: The basophils of pars intermedia invaded pars nervosa as age advanced. These basophilic cells contained ACTH/MSH granules in their cytoplasm. This basophilic invasion with increasing age is purely a physiologic phenomenon as evidenced by the increasing pigmentation with age.

KEY WORDS: ACTH/MSH granules, Basophils, Basophilic invasion, Pars intermedia.

Address for Correspondence: Dr Savithri Krishnan, Professor in Anatomy, Govt Medical College, Kollam, Kerala, India.Tel No: 09495994490 E-Mail: drsachi@gmail.com

\section{Access this Article online}

\section{Quick Response code}

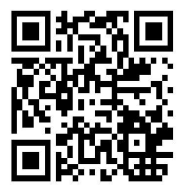

DOI: $10.16965 /$ ijar.2017.125

Web site: International Journal of Anatomy and Research ISSN 2321-4287

www.ijmhr.org/ijar.htm

Received: 26 Jan 2017

Peer Review: 27 Jan 2017

Revised: None
Accepted: 02 Mar 2017

Published (O): 31 Mar 2017

Published (P): 31 Mar 2017

\section{INTRODUCTION}

The pituitary gland, also called hypophsis cerebri, has two major divisions differing in origin, structure and function. They are the adenohypophsis and neurohypophysis. The adenohypophysis is the ectodermal derivative and includes the pars anterior, pars intermedia and pars tuberalis. The neurohypophysis is the neuroectodermal derivative and includes the pars nervosa, infundibulum and median eminence. The intra glandular cleft, Rathke's cleft, lies between the pars anterior and the pars intermedia [1].
The pars intermedia or the intermediate lobe of pituitary is named so from the fact that it is interposed between the pars anterior and pars nervosa. The morphology of pars intermedia varies in different animals and in man. More than a century has passed from the ancient days of Peremeschko [2] in 1863 who first described the pars intermedia of pituitary gland. The pars intermedia is most variable in size, shape and function among various animal species [3]. It is well developed in most vertebrates but absent in birds and in some animals like elephants and whales [4]. In human fetus it forms about 3.5\% 
of the glandular portion of the pituitary while in adults it forms about $2 \%$ [4].

Most of the research works done on the pituitary pars intermedia are immunocytological studies and are mostly done in animals. The present study is a light microscopic study of the human pituitary pars intermedia and is a histologic and histochemical attempt to appreciate the basophil cells and the nature of secretion of these cells at various ages of life and to correlate these with age.

Fig. 1: The different parts of pituitary gland.

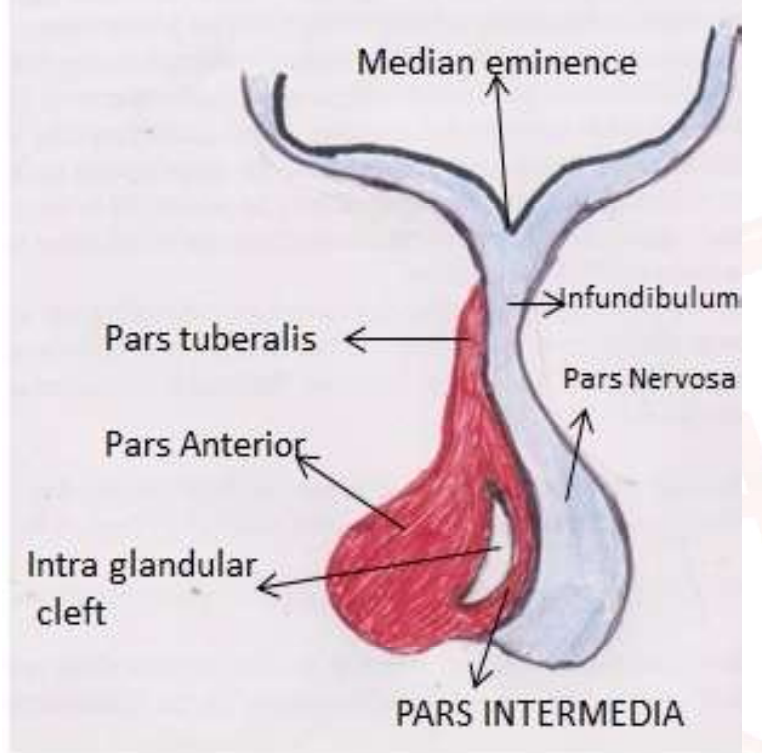

\section{MATERIALS AND METHODS}

83 specimens of pituitary were included in this study. These included specimens of both sexes from fetuses of 18 weeks of gestation to full term and also from four years to 80 year old. The specimens of fetuses were collected from the Department of Obstetrics \& Gynecology and those of adults and children from the autopsy specimens from the Department of Forensic Medicine, Govt Medical College, Trivandrum, Kerala, India. The exclusion criteria in this study were those in which postmortem was done after 6 hours following death or those in which there were history or findings of head injury. Fetuses with neurological congenital anomalies were also excluded from this study. Research technical committee and ethical committee clearance was obtained from the institution.

After removal of the skull cap, the meninges were cut and the brain was removed. The diaphragma sella was cut and removed and the pituitary gland was gently scooped out en mass. All the specimens were immediately transferred to the fixative solutions to avoid any postmortem changes from setting in. The fixatives used were $10 \%$ formalin, Bouin's fluid and Helly's fluid [5]. The fixed specimens were subjected to routine histological processing. The blocks thus obtained were sectioned at $\mathbf{0 . 5}$ micron. Serial sections were also taken. The slides were numbered and the key to these numbers contained the age and sex of the persons from whom the specimens were taken.

These sections were then subjected to histological and histochemical staining methods. Histological staining methods included Haematoxylin \& Eosin, Chrome Alum Haematoxylin and Phloxine [5]. Histochemical staining techniques used in this study were the Periodic Acid Schiff (PAS) Reaction [5] and the Naphthyl Ethylene Diamine (NED) Condensation Reaction .[6] PAS staining was done to demonstrate the presence of glycoproteins in the cells. The NED condensation reaction was done to demonstrate the Sulphur containing amino acid Tryptophan. Tryptophan was present at the $\mathrm{N}$ terminal end of the proteins present in the ACTH/MSH containing cells of the pituitary.

The area between pars anterior and pars nervosa, which formed the pars intermedia, was studied in detail under ordinary light microscope. The cell types in this area, their special staining characteristics and their extent were examined.

\section{RESULTS}

Type of cells: The types of cells observed in all the sections were mainly basophils, very few acidophils, chromophobes and the usual connective tissue cells (viz- lymphocytes and fibroblasts). The basophils formed the majority of cells and were arranged in between the follicles in groups. Acidophils and chromophobes were few in number when compared with basophils. The follicles were lined with basophils and contained eosinophilic colloid in them.

In the sections of the pituitary of the fetus, the glandular cells of pars intermedia were seen to be arranged in groups to one side of the Rathke's cleft. Fig $2 \mathrm{~A}$ shows the different parts of the pituitary gland of a fetus aged 18 weeks under light microscope. 
Fig. 2A: Section of pituitary of 20 week fetus- PAS Stainingshowing the different parts of pituitary. PA- Pars Anterior, PI- Pars Intermedia, PN- Pars Nervosa, RC- Rathkes Cleft

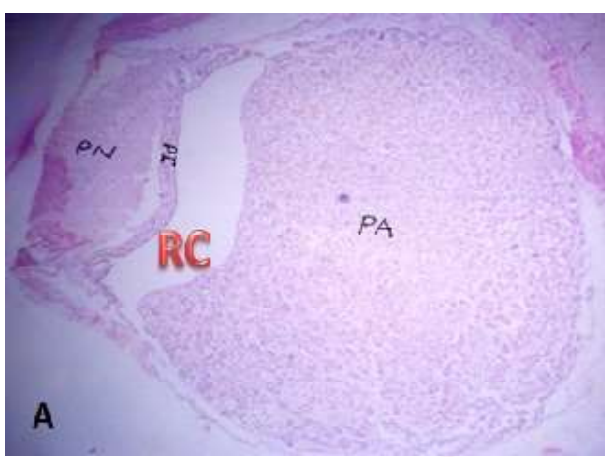

These glandular cells of the pituitary pars intermedia cells were polygonal, basophilic and with large vesicular nucleus. They also contained PAS+ ve granules. Acidophils were few and chromophobes were absent. Follicles with colloid were also not seen in the sections.

Fig. 2B: Section of 20week foetus- Chrome Alum Haematoxylin Phloxine stain. Note the Basophils located to one side of the cleft

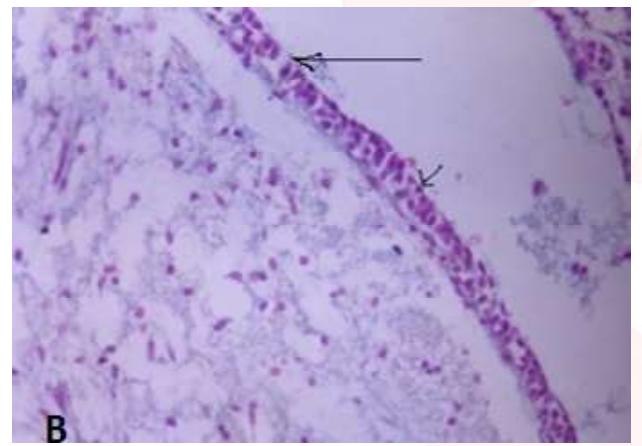

As age advanced the number of basophils increased. These basophils were arranged in groups in between the follicles. The follicles were lined by basophils and contained colloid in them. Acidophils and chromophobes were also present but were few when compared with the basophils.

Fig. 3A: Section of 26 yr old :H\& E stain showing basophils (B) arranged in groups (A).

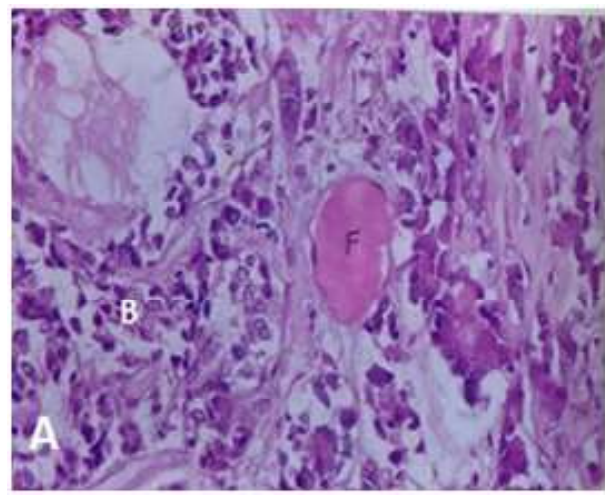

The number of follicles increased as age advanced. These follicles were lined by baso- phils. Basophils were also seen in between the follicles in small groups.

Fig. 3b: Section of a 38 year old stained with Chrome Alum Haematoxylin Phloxine - showing well developed Pars Intermedia and plenty of Basophils (B) arranged in groups and follicles

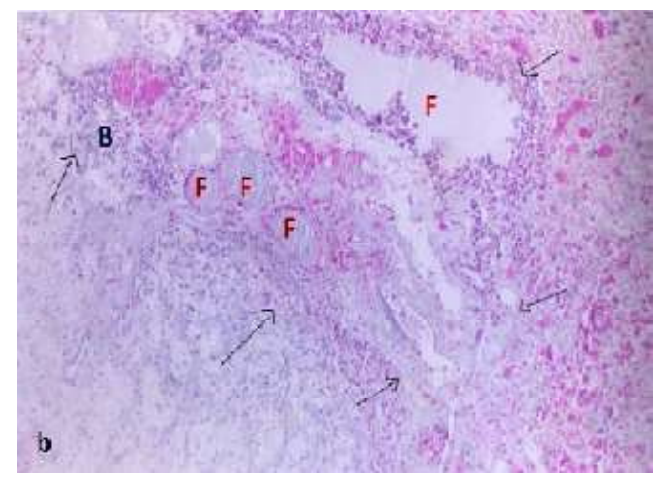

Special staining / Histochemistry: With PAS staining, the cells revealed a positive reaction indicating the presence of PAS+ve granules in the cytoplasm of basophils. This gave the confirmatory presence of glycoproteins/mucoproteins present in the cytoplasm.

Fig. 4 A: Section of $55 \mathrm{yr}$ old- PAS staining: Showing PAS + ve cells of the pars intermedia.

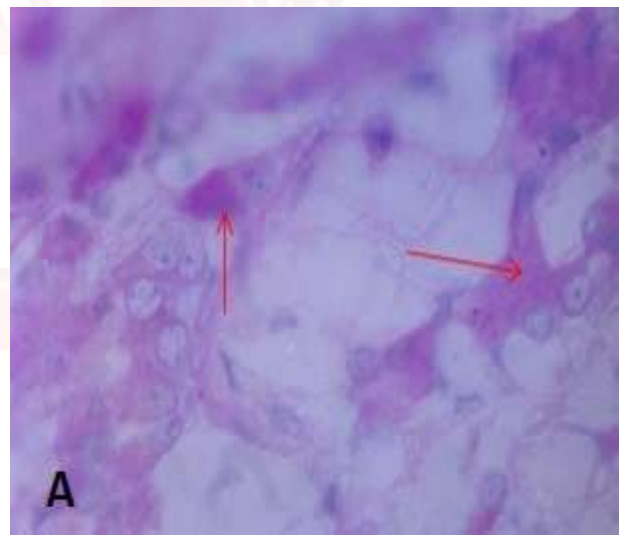

Fig. 4B: Section of a $62 \mathrm{yr}$ old - NED condensation reaction: showing cells with purple granules in the cytoplasm.

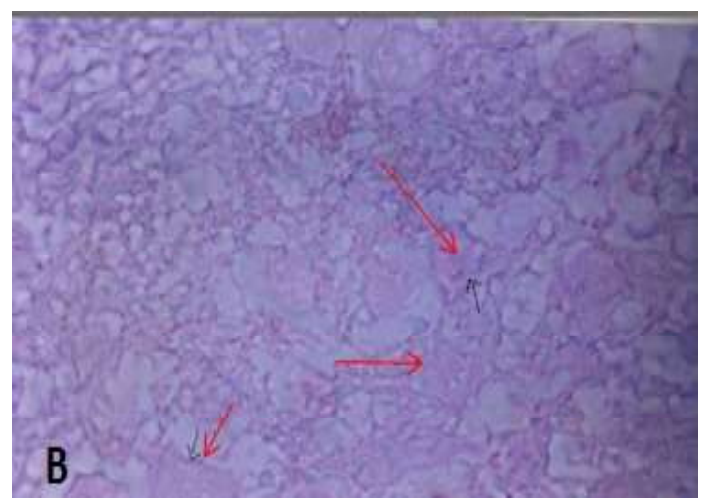

The NED condensation reaction showed purple granules in the cytoplasm of the basophils. These basophils were present in pars anterior and pars intermedia. This positive NED condensation 
reaction by the basophils clearly indicated the presence of tryptophan at the $\mathrm{N}$ - terminal end. The presence of tryptophan confirms the presence of ACTH/MSH in the cytoplasmic granules of the basophils.

Extent / Infiltration: the basophils were located to one side of the Rathkes cleft in the fetuses and were also seen as groups in between the follicles as age advanced. The basophilic cells invading pars nervosa was observed in the section of an 18 year old.

Fig, 5A: Section of $18 \mathrm{yr}$ old - Chrome Alum Hematoxylin Phloxine stain - note the basophils invading pars nervosa.

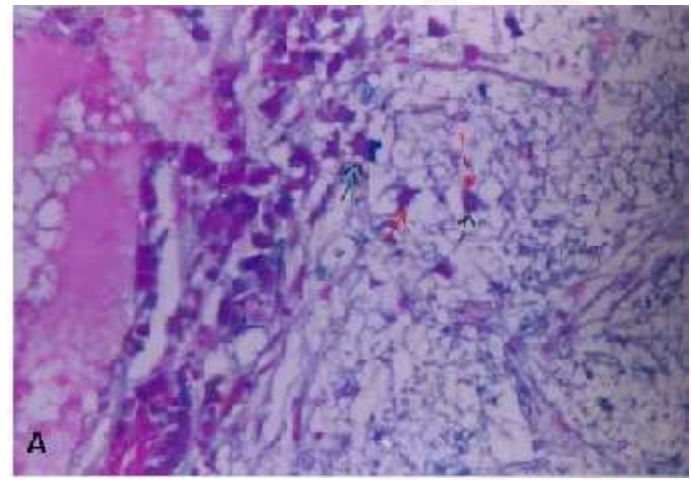

The number of basophils invading increased with age and a massive invasion into pars nervosa was seen in the gland of an 80 year old, the highest age included in the present study (Ref: Fig 5 B). The invading cells were also polygonal in shape with basophilic cytoplasm and also had PAS+ ve granules in the cytoplasm. These cells were found to fill up the pars intermedia and migrated towards pars nervosa.

Fig. 5B: Section of an $80 \mathrm{yr}$ old - Hx \& E stain- - note the massive invasion of basophils into pars nervosa.

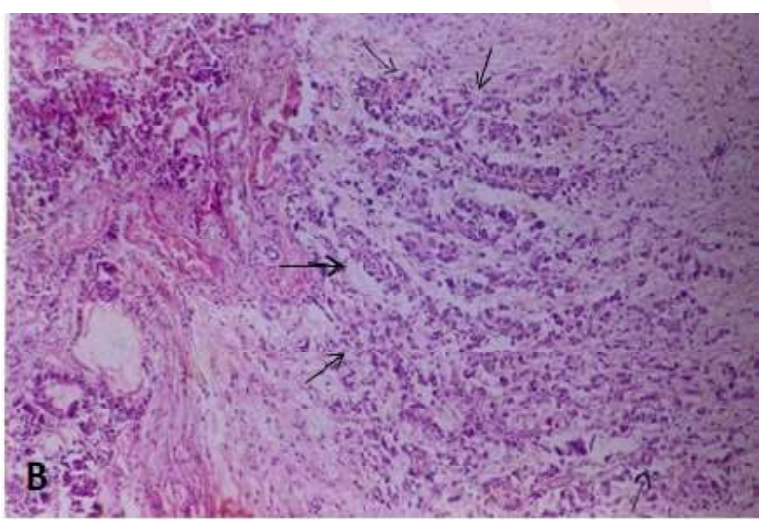

In order to determine the chemical nature of the granules in the cytoplasm of the invading cells, the NED condensation reaction was done. These invading cells, similar to the basophils of pars intermedia also showed a positive reaction by taking up a purple color. This indicated the presence of tryptophan at the $\mathrm{N}$ terminal end.

Fig. 6: Section of 80 yr old. NED Condensation reaction note the purple granules in the cytoplasm of the cells.

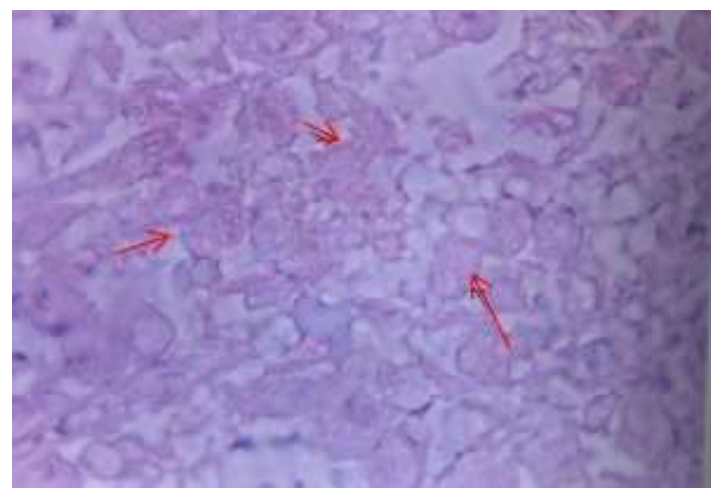

\section{DISCUSSION}

Basophils with PAS+ glycoprotein granules formed the majority of cells in the pars intermedia of the fetal pituitary. They were seen as early as 18th week of gestation in the present study. The basophils were seen at 7th week of gestation by Asa [7], Horvath [8] by 12th week of gestation and secreted ACTH; but Visser [9] and Ikeda [10] observed them only by 21st week of gestation. Immune reactivity studies reported that these cells secreted ACTH/ "MSH.

As age advanced basophils increased in number and were seen as small groups in between the colloid filled follicles. These basophils were PAS+ and contained glycoprotein granules. They also contained $\mathrm{N}$ tryptophyl peptide present in ACTH/ MSH producing granules as shown by the special histochemical studies. Histochemical and Immuno histochemical staining reactivity done by, Horvath [8], , Leznoff [11], Fan X [12] and Yamashita [13] also reported the presence of basophils seen as groups and clusters in pars intermedia and these cells secreted ACTH/ POMC ( Pro Opio Melano Corticotropin).

The basophils in the pars intermedia infiltrated the pars nervosa and this basophilic invasion increased with age. These invading cells also had PAS+ve granules and contained tryptophan at its $\mathrm{N}$ terminal end which is a content of ACTH/ $\mathrm{MSH}$. The origin of the basophil cells in the pars nervosa was first described by Rasmussen [14] as early as 1930 . This was further confirmed by Celio [15], and Phifer [16]. Immunocytochemical studies of Horvath [8], Yamashita [13] and 
Fan $X$ [12] revealed that the cells in pars intermedia contained $S$ containing Tryptophan and showed both MSH and ACTH activity, indicating that both MSH \& ACTH were synthesized in the same cell. These findings were also in conformity with the works of Lowry \& Scott [17] and Brown [18]. The presence of tryptophan at the $\mathrm{N}$ terminal end of $\mathrm{ACTH} \& \mathrm{MSH}$ granules was also reported by Purves [19], Hakanson [20].

The basophils that invaded pars nervosa originated from pars intermedia. This was further confirmed by the works of Purves [19]. Horvath [8], Hanstrom [21], Fand [22]. Fan X. [12] had explained that the corticotrophs in the basophilic invasion are undergoing proliferation in the intermediate lobe and are different from their counterpart in anterior lobe. The present study also showed that the invading cell contained ACTH/MSH granules as demonstrated by histochemical staining methods and is most probably MSH or its precursor granules as evidenced by increasing pigmentation with age. If all the invading cells secreted ACTH, symptoms of increased ACTH would appear with ageing. This view is also shared by Horvath [8], Hakanson [20].

\section{CONCLUSION}

Basophils formed the majority of cells in the pars intermedia of human pituitary. The basophil cells contained glycoprotein and ACTH/ MSH granules in their cytoplasm. These basophils invaded pars nervosa with increasing age and this basophilic infiltration is a purely physiologic phenomenon as evidenced by increasing pigmentation with age.

\section{Conflicts of Interests: None}

\section{REFERENCES}

[1]. Dutta A.K .Essentials on Human Embryology 2005; 5th edition 137-138.

[2]. Peremeschko 1867. Cited by Virchow in Harris GW \& Donovan BT eds ; The Pituitary Gland 1966;(I):127

[3]. Kurusomi K, Fizula H .Adenohypophysis-Functional Morphology of Endocrine Glands 1975;(3):84-101.

[4]. Purves HD.Cytology of the adenohypophysis-cited in Harris GW \& Donovan BT eds; The Pituitary Gland;1966;(I):147-234.

[5]. Mc Manus, J.F.A and Mowry, R.W.Staining methodsHistologic and Histochemical; Paul, B. Hoeber, Inc. Med. Divn of Harper \& Brothers; 1960.
[6]. Pearse AGE .Chapter1 Analytical technology. Histochemistry. Theoretical and applied.4rth ed 5-69.

[7]. Asa SL, Kovacs K, Singer W .Human Fetal adenohypophysis, Neuroendocrinology 1991;(53):562-562.

[8]. Horvath E, Kovacs K.Lost and found - The Pars Intermedia of the Human Pituitary and its role in the histogenesis of silent corticotropic adenoma. ; Endocrine Updates, 2003;(21):259-275.

[9]. Visser M, Swab Al. Life Span Changes in the presence of "-melanocyte stimulating hormone containing cells in the human pituitary; J Devel physiology, 1979;(1):161-178.

[10]. Ikeda H, Suzuki J, Sasana N.The development and morphogenesis of the human pituitary gland, Anat \& Embryology;1988;178(4):327-336.

[11]. Leznoff A, Fishmann J, Talbot M ,Mc Garry EE etal, Cytological localization of ACTH in the human pituitary. J.Clin Invest 1962;41:1720-1729.

[12]. Fan X, Olson SJ, Johnson. Immunohistochemical localization \& comparison of Carboxypeptidase D Eand Z,"MSH-ACTH and MIB-1 between Human anterior corticotropin cell \& Basophil Invasion of posterior Pituitary; ; J. Histochem. Cytochem, 2001;(49):783-790.

[13]. Yamashita M, Sano T, Qlanz R. Diversity of ACTHimmunoreactive cells in the human hypophysisEndocrine Pathology, 2006;(17):55.

[14]. Rassmussen AT.Origin of the basophil cells in the posterior pituitary of human hypophysis. Am J. Anat 1930;(46):461-475.

[15]. Celio MR, Pasi A, Burgisser. E , Buetti. G .Pro opiocortin fragments in normal human adult pituitary- Distribution and Ultra structural characterization of immunoreactive cells. Acta Endocrinol 1980;(95):27-40.

[16]. Phifer RF, Spicer SS, Hennigar GR. Histochemical reactivity \& Staining properties of functionally defined cell types in adenohypophysis-Am.J Pathol 1973;17(39):569-588.

[17]. Lowry PJ, Scott AP.The evolution of vertebrate corticotrophin and melanocyte stimulating hormone. Gen. Comp. Endocrinol, 1975;(26):18-32.

[18]. Brown J D .Pituitary pigmentary hormones - JAMA ,1978;240(12):1273-1278.

[19]. Purves HD, BasettEG .Staining reactions of Pars Intermedia cells \& their differentiation from Pars anterior cells.. Acta Endocrinol ;1980;(95):27-40.

[20]. Hakanson R, Sundler F, Larson LL, Ekman R etal .Peptides with $\mathrm{NH} 2$ terminal tryptophan in ACTH and MSH granules of Adenohypophysis- J. Histochem. Cytochem 1975;(23):65-69.

[21]. Hanstrom.B.Hypophysis in Primatologia 1957- cited in Harris GW , Donovan ed The pituitary gland 1966;(3):1-27.

[22]. Fand S.B .Glandular Epithelial Cells in Pars nervosa, Histochemistry, Distribution and possible clinical significance. Am. J. Clin. Path 1961;35:210-221.

How to cite this article: Savithri Krishnan, Aleyamma Fenn. BASOPHILS OF HUMAN PITUITARY PARS INTERMEDIA. Int J Anat Res 2017;5(1):3629-3633. DOI: 10.16965/ijar.2017.125 